\title{
Analytical Approaches and Trends in the Determination of Psychoactive Drugs in Air
}

\author{
Phillippa Zambas-Adams and Kevin C. Honeychurch *
}

check for updates

Citation: Zambas-Adams, P.; Honeychurch, K.C. Analytical Approaches and Trends in the Determination of Psychoactive Drugs in Air. Sci 2022, 4, 1. https:// doi.org/10.3390/sci4010001

Academic Editors: Ahmad Yaman Abdin and Claus Jacob

Received: 17 September 2021 Accepted: 12 November 2021 Published: 1 January 2022

Publisher's Note: MDPI stays neutral with regard to jurisdictional claims in published maps and institutional affiliations.

Copyright: (c) 2022 by the authors. Licensee MDPI, Basel, Switzerland. This article is an open access article distributed under the terms and conditions of the Creative Commons Attribution (CC BY) license (https:/ / creativecommons.org/licenses/by/ $4.0 /)$.

\author{
Centre for Research in Biosciences, Department of Applied Sciences, University of the West of England, \\ Frenchay Campus, Bristol BS16 1QY, UK; Phillippa2.Zambas-Adams@live.uwe.ac.uk \\ * Correspondence: kevin.honeychurch@uwe.ac.uk
}

\begin{abstract}
Understanding of the levels of psychoactive drugs in air is important for assessing both occupational and environmental exposure. Intelligence on the usage and manufacture of illegal drugs can also be gained. Environmental analysis and determination of air quality has recently expanded from its traditional focus to new pollutant categories that include illicit and psychoactive drugs. This is attributed to a greater part on the development of new, advanced techniques, such as liquid chromatography/mass spectrometry (LC/MS), allowing for the trace determination of such compounds down to the parts-per-trillion (ng/L) levels generally reported in air. Studies have also investigated the effects of firsthand and secondhand smoking of drugs, such as cocaine, cannabis and opium. Generally, these have shown secondhand smoke effects to be limited, apart from in the case of opium. Some studies have highlighted ill effects resulting through the exposure of vapors and dusts from the storage of drugs, but this has been shown to result from mould and other fungal contaminates. Investigations into the possible occupational exposures resulting from the use of anesthetic drugs in surgery and accident and emergency have focused on nitrous oxide, sevoflurane, methoxyflurane, isoflurane, propofol and fentanyl. This review focuses on developments and applications for the determination of psychoactive drugs in air.
\end{abstract}

Keywords: LC/MS; GC/MS; air; cocaine; opium; cannabis; opiates; methamphetamine; nitrous oxide

\section{Introduction}

The presence of drugs and their residues have been shown in various media, including drinking [1] and wastewater [2], the surfaces of many public buildings [3], hospitals [4] and police stations [5]; on commonly encountered items such as banknotes [6] and clothing [7]. The determination of low, trace levels of drugs in these settings has become more common as detection limits become increasingly improved by advances in analytical instrumentation, such as liquid chromatography triple quadrupole tandem mass spectrometry (LC/MS/MS). There has been a great deal of interest in the determination of drugs and their vapours for their detection in the illicit trade in instances, such as smuggling and for their possible environmental effects. This review aims to present the current analytical methods applied for the determination of psychoactive drugs in air.

Investigations into the levels of drugs present in air have been of interest for some time [8], with early reports focusing on the determination of caffeine and nicotine. Semiquantitative analysis of caffeine in air has been described as early as 1964 by Ordoveza and West [9]. In 1977, Dong et al. [10] investigated the levels of caffeine in the air of New York City (USA). Its concentration in two samples collected in the period from January to April 1975 were reported to be $3.4 \mathrm{ng} / \mathrm{m}^{3}$ and $7.0 \mathrm{ng} / \mathrm{m}^{3}$, respectively. This was concluded as resulting from the numerous coffee roasting plants present at the time, both in New York City itself and the adjacent New Jersey. Investigations in the mid-1980s were carried out on the determination of nicotine in indoor air [11,12]. The determination of tobacco smoke in air were reviewed by Pandey and Kim in 2010 [13], and for the determination of nicotine in air, were reviewed by Apelberg et al. [14]. 
As early as 1970, the application of mass spectrometry was discussed [15] for the determination of drug vapour in air. In this early report, it was shown possible to introduce air directly to the mass spectrometer via a dialysis cell, overcoming the issues of introducing trace levels of drug in the presence of relatively large quantities of water from the air. It was shown that it was possible to analyse volatile drugs, such as diethyl-ether, ethanol and methyl-parafynol in both indoor and laboratory air. Samples were also taken of either breath or from the forearm after four or five breaths of ether. This was found sufficient to show very high intensities of the characteristic ions. The presence of diethyl-ether on the breath was still reportedly detectable after six hours. Further investigations into the possibility of the detection of methamphetamine in the vapour above an aqueous solution and for chlorpromazine vapour obtained above crystals of the drug showed the possibility of the detection of other drugs. The authors reported that about two-thirds of the most commonly prescribed drugs could be detected in a similar manner. Investigations also showed the possibility of determining both marijuana and hashish from the vapour above a sample of cloth used previously to rap it. Further investigations showed the possibility of being able to differentiate this vapour from basil, tarragon, cloves, oregano and black pepper. However, the technique was found to be less successful for the identification of nicotine in tobacco smoke. Presumably, this was due to the relatively small amounts of nicotine that would be present compared to the large number of other compounds that a burning a cigarette would generate and hence interfere. Quantitative results were also shown possible, by placing aqueous drug solutions in one half of a dialysis cell and drawing the air or nitrogen from the other half of the cell into the mass spectrometer.

One interesting example of the effects of illicit drugs in air are the events involving the Spanish women's field hockey team in 2008 [16]. Having won all their matches in their Olympic prequalifying tournament held in Baku, Azerbaijan in 2008, the team had gained a place at the 2008 Beijing Summer Olympics. Unfortunately, following analysis at the antidoping laboratory of Moscow, the Spanish National hockey team were informed that samples from two of their players showed an adverse analytical finding. Both players were found to have tested positive for 3,4-methylenedioxymethamphetamine (MDMA) in their urine at concentrations of $4 \mu \mathrm{g} / \mathrm{mL}$ and $60 \mu \mathrm{g} / \mathrm{mL}$, respectively. Under the rules of the FIH Anti-Doping Policy, such findings could result in the disqualification of the whole team. After having dinner at their hotel on the night of 17 April 2008, 12 members of the Spanish National team, along with the president of the Spanish Hockey Federation, his wife and both the coach, and their assistant, along with the team doctor reported symptoms of vertigo, leg weakness, dizziness, and tremors. They had successfully asked for the air conditioning outlet over their table to be switched off. However, this was subsequently switched back on. Team members who had also been present at the event reported a "white powder" falling on them. The Spanish Hockey Federation initiated an appeal process to show that contamination through the team's hotel air ventilation and tampering of a urine sample had occurred, and were able to overturn the sanctions imposed on the Spanish National Team.

\section{Exposures to Second and Thirdhand Smoke}

Early investigations of both the chemistry and the effects the smoking of drugs smoking and the subsequent exposure to secondhand smoke has been reviewed in a monograph by the U.S. Department of health and Human Services [17]. This report focused on the clinical effects of smokers on others. However, no mention is made to analytical methodology.

\subsection{Cannabis}

More readily noticeable air pollution is that resulting from the smoking of materials such as marijuana. Recently, Holitzki et al. [18] reviewed the health effects of second- and third-hand marijuana smoke. In two separate studies, Cone et al. [19] investigated the effects of secondhand marijuana smoke. They exposed five male drug-free volunteers with a previous history of marijuana use to the side stream smoke from 4 to 16 marijuana cigarettes 
(2.8\% $\Delta$-9-tetrahydrocannabinol) for one hour per day over six consecutive days. In a further study, two marijuana-naive subjects were passively exposed to the smoke of 16 marijuana cigarettes. The investigations were conducted in a small, unventilated room. Air samples were collected from a room port, $1.16 \mathrm{~m}$ above the ground, via solid phase adsorption (Gas-Chrom Q) methanol was then used to elute the absorbed $\Delta$-9-tetrahydrocannabinol, which was then derivatised with $N$-methyl- $N$-trimethylsilyl-trifluoroacetamide. Levels of $\Delta$-9-tetrahydrocannabinoll were then determined by gas chromatography with flameionisation detection. $\Delta$-9-tetrahydrocannabinol levels in the air were reported to increase rapidly during combustion of the marijuana cigarettes, reaching a plateau and then slowly declining. With the door to the room sealed, air concentrations of $\Delta-9$-tetrahydrocannabinol were reported between $0.9-1.8 \mu \mathrm{g} / \mathrm{L}$ and 3.0-6.7 $\mu \mathrm{g} / \mathrm{L}$, respectively, during smoking of 4 and 16 marijuana cigarettes. In the high-level exposure studies, the authors reported that all subjects showed significant levels of absorbed $\Delta$-9-tetrahydrocannabinol, with measurable levels of the main metabolite, 11 -nor-9-carboxy- $\Delta$ 9-tetrahydrocannabinol in their urine. Low level exposure resulted in specimens that tested positive only infrequently or were negative. The authors did also note that it was unlikely that individuals would wittingly tolerate the high smoke levels and conditions produced in the high smoke exposure studies.

In a recent study by Herrmann et al. [20], the effect of secondhand cannabis smoke generated by six individuals smoking cannabis in a specially constructed chamber. The effects of ventilation were investigated and the effect on physiological, behavioural and cognitive measures studied. Under unventilated conditions, all six subjects had detectible levels of $\Delta$-9-tetrahydrocannabinol following exposure to secondhand smoke. Investigations by enzyme-linked immunosorbent assay (ELISA) and confirmation by gas chromatography mass spectrometry (GC/MS) $>15 \mathrm{ng} / \mathrm{mL}$ showed that at four hours post-exposure four out of six of the non-smoker's urine samples were confirmed positive for the principle $\Delta$-9-tetrahydrocannabinol metabolite, 1-nor-9-carboxy- $\Delta$-tetrahydrocannabinol, 2 to $22 \mathrm{~h}$ post secondhand smoke exposure.

Sempio et al. [21] investigated the possibility of detecting cannabinoids on surfaces and objects resulting from the application of vapours. Their aim was to investigate the possibility of cannabis vapour forming thirdhand smoke exposure following vaping. Surfaces were sampled with cotton swabs with water and isopropanol alcohol $(30: 70 \mathrm{v} / \mathrm{v})$. The exposed swabs were soaked in methanol containing the internal standard, $\Delta 9$-tetrahydrocannabinol$\mathrm{d}_{3}$. A $1.2 \mathrm{~mL}$ aliquot of this was then taken and evaporated to dryness. Following being reconstituted and vortexing with methanol/water, the supernatant was examined by liquid chromatography-tandem mass spectrometry. Out of the fifteen surface samples, only six were found to exhibit quantifiable levels of $\Delta$-9-tetrahydrocannabinol, exhibiting levels ranging between $348-4882 \mathrm{ng} / \mathrm{m}^{2}$.

\subsection{Cocaine}

Further investigations into the passive smoke exposure arising from 'crack' cocaine smoking has been reported by Cone, et al. [22]. In their initial study, six male volunteers were subjected to the vapor formed from 100 and $200 \mathrm{mg}$ of freebase cocaine heated to $200^{\circ} \mathrm{C}$ in an unventilated room for one hour. No pharmacological effects were reported and blood samples obtained directly after exposure were reported to be negative for cocaine and its metabolites. However, GC/MS investigations of urine samples showed peak benzoylecgonine concentrations ranging from 22 to $123 \mathrm{ng} / \mathrm{mL}$ with a peak excretion time for the main metabolite, benzoylecgonine of approximately five hours. A passive inhalation study, undertaken on research staff investigating "crack" smokers showed that being passively exposed to three doses of freebase cocaine $(12.5,25$, and $50 \mathrm{mg}$ ) over a period of $4 \mathrm{~h}$ resulted in only very low urine levels of both benzoylecgonine $(<6 \mathrm{ng} / \mathrm{mL})$ and cocaine $(<1 \mathrm{ng} / \mathrm{mL})$ being recorded. It was concluded that individuals absorbed only small amounts of cocaine from passive smoking and these levels were insufficient to show urine levels above the USA Department of Health and Human Services cut-offs. 
Bitter [23] has simulated the effect of the smoking of cocaine and methamphetamine and the formation of third-smoke. Here, the drugs were volatilised and the vapour allowed to collect on silicon, plastic, laminate, and artificial leather surfaces materials for over a period of four weeks. The surface was then examined by electrospray ionisation-mass spectrometry. The parent molecule was still detectable after four weeks, demonstrating the persistent nature of these drugs.

\subsection{Opium}

The indoor environment of homes in Afghanistan where opium and opium products, such as heroin, are abused have been studied [24]. Air, surfaces and hair of occupants were sampled to investigate the possibility of second hand and third hand exposure to opium products to non-drug users and children. Air samples were collected by drawing air through a column at $1000 \mathrm{~mL} /$ minute for $30 \mathrm{~min}$. Opium products detected in indoor air samples were reported as significant. From the 20 smoking homes, 12 out of the 13 air samples obtained were reported to be positive. Air samples collected in actively opium smoking houses were reported to give levels of morphine, codeine and 6-acetylmorphine of trace, or below the limit of detection, of up to $2.00 \mu \mathrm{g}, 1.86 \mu \mathrm{g}$ and $1.26 \mu \mathrm{g}$ per sample tube respectively for a $30-$ min collection time. As well as the air drug concentration in the homes investigated, the authors reported the levels of morphine, codeine and heroin metabolites in the occupants' hair and also the surfaces of the homes investigated. One particular example provided by the authors was the level of opiates found in the hair sample obtained from a 10-year-old girl, which exhibited a level of $5607 \mathrm{pg} / \mathrm{mg}$ of a 6acetylmorphine one of the principle metabolites of heroin and $8350 \mathrm{pg} / \mathrm{mg}$ of morphine, a known secondary metabolite of heroin along with $4652 \mathrm{pg} / \mathrm{mg}$ of codeine. This was reported to be comparable to that obtained from heroin addicts.

\section{Forensic and Public Health}

\subsection{Clandestine Methamphetamine Laboratories}

Buildings previously used for the clandestine manufacture of methamphetamine are required in a number of countries to be tested for the residues of drug and related chemicals, before they can be reused. Commonly, these methods are focused on the determination of surface residues. However, in a recent study by McKenzie et al. [25], a possible alternative approach, based on the determination of air levels of methamphetamine, was explored. The authors developed an air methamphetamine field sampling device based on a solid phase microextraction (SPME) fibre held in the air flow of an air sampling pump. Investigations were carried out on 21 suspected former clandestine methamphetamine laboratories. Samples were taken at a flow rate of $1.00 \mathrm{~L} / \mathrm{min}$ for 5-30 min, whilst the investigator walked through the house. The sampler was held at chest level, as to sample the air intake zone for normal breathing. A number of static SPME measurements were also made. In these investigations the SPME fibre was positioned at about $30 \mathrm{~cm}$ above a given surface. Sixty-five different compounds were identifiable, but only methamphetamine, 1-phenyl-2-propanone and $N$-formylmethamphetamine were indicative of drug use or manufacturing. The remaining compounds were concluded to originate from a range of compounds present in most residents, such as cleaning agents, insecticides and repellents, air fresheners, plant and food volatiles, cosmetics, perfumes, fuels, textile surface treatments and plastics. Further investigations [26] were conducted into the possibility of sampling for methamphetamine vapour use of capillary microextraction for the sampling airborne methamphetamine. Comparisons were made with the previously reported dynamic SPME method described above [25]. The capillary microextraction devices consisted of a glass tube containing a PDMS-coated glass filter strip. Under identical sampling conditions, these devices were reported to be approximately 30 times more sensitive than the dynamic SPMEs. 


\subsection{Drug Precursors}

The determination of the air levels of one such chemical reagent, acetic anhydride; commonly employed in the chemical conversion of morphine to heroin and the synthesis of methaqualone has been reported by Bocos-Bintintan et al. [27], utilising photoionisation detection (PID) and ion mobility spectrometry (IMS). Both PID and IMS were shown to able to determine trace levels of acetic anhydride in air, but PID was reported to be less selective. Measurements using a portable, commercial IMS system in negative ion mode were reported to be able to measure concentrations of $0.05 \mathrm{ppmv}\left(0.2 \mathrm{mg} / \mathrm{m}^{3}\right)$.

\subsection{Synthetic Cannabinoids}

Recently, two-dimensional gas chromatography coupled to time-of-flight mass spectrometry (GC $\times$ GC-TOF MS) [28] has been applied to investigate the concentrations of synthetic cannabinoids in the air of an English prison. Air samples were collected using both fixed sequential samplers and personal air sampling units worn by prison officers. Air samples were collected onto thermal desorption tubes. GC $\times$ GC-TOF MS analysis was shown to be able to successfully separate and identify a range of compounds present in the prison air samples. However, analysis of the TD tubes from the fixed pump air samples or the personal pump samples worn by prison officers did not reveal the presence of any synthetic cannabinoids.

\subsection{Police Drug Storage Units}

Elevated concentration of volatile compounds can result from the storage of drugs in confined spaces. The resulting smell associated with drugs can be a concern to those experiencing it. Reportedly, over 200 different compounds contribute to the odour of cannabis [29], predominated by many of the chemicals emitted commonly by many plant species. The psychoactive component, $\Delta$-9-tetrahydrocannabinol was not reported as a volatile component $[30,31]$. However, in confined spaces under extremes of temperature and humidity, $\Delta$-9-tetrahydrocannabinol can be volatile and be reportedly found at concentrations high enough to be detectable by air samplers [30]. Residue chemicals used in the preparation and synthesis of drugs can also be volatile. The preparation of drugs, such as cocaine, can potentially use diesel or petrol to extract cocaine from the coco plant [32]. Potentially dangerous solvents, such as chloroform, acetone, hydrochloric acid, ammonia, ether and methylethylketone are commonly also used in drug preparation and synthesis. Studies of a police drug store unit in Kentucky (USA) showed particulate concentrations of between $2.8-5.2 \mathrm{ng} / \mathrm{m}^{3}$ of methamphetamine and cocaine levels up to $12,000 \mathrm{ng} / \mathrm{m}^{3}$ in one air sample. Oxycodone, cocaine and $\Delta$-9-tetrahydrocannabinol levels were found at the minimum detectable concentrations of $0.3,20$ and $1.5 \mathrm{ng} / \mathrm{m}^{3}$, respectively [33]. The study showed levels of drug particles found in air and on surfaces present a potential health risk to employees. The volatile organic chemicals measured in air were components from marijuana plant itself and were reported to unlikely lead to adverse health issues. However, there was mould found on containers holding plant-based drugs and it was concluded that many of the variety of health symptoms reported by the employees more likely to result from this, rather than drugs themselves. Investigations on indoor and outdoor air sampling for mould and the personal breathing zone (PBZ) air for chlorine, ethyl ether, naphthene, benzene, xylene, and toluene have been undertaken. Results showed the presence of the mould, Chaetomium in indoor air samples, commonly found in soil and decaying plant matter. Its presence was concluded to result from mould growing on the cannabis plant material and container boxes. All PBZ results were reported to be below the detection limits.

In a similar boarder study, Doran et al. [34] have investigated air samples from eight drug safes and a small storage room at nine city and country police stations, and a centralized drug evidence storage vault, in New South Wales, Australia. The possibility of airborne drug residues was explored using charcoal containing sorbent tubes. The tubes were analysed by LC/MS/MS for 22 drug residues and two metabolites. The presence of 
volatile organic compound residues was sampled using sorption tubes and SPME fibres and quantified by GC/MS. No detectable drug residues, in either the airborne dust or vapor, were reported in the safes, the storage room or the large central repository vault. No drugs were reported present in the 34 urine samples collected at eight of the 10 locations investigated. However, analysis of volatile organic compounds showed a variety of solvents commonly associated with drug manufactures, plasticisers, personal care products and volatiles associated with plants including cannabis. Similarly, this study concluded that odours resulting from drug evidence safes are unlikely to be drug residues, but more likely to result from the volatile organic compounds associated with drug manufacture or used in plant growing operations.

\section{Air Pollution}

\subsection{Commercial Cannabis Farming Air Pollution}

The aroma profiles generated for the cannabis plant were studied in the early 1970s [35]. More recently, Wang et al. [36] investigated effects of legal commercial cannabis cultivation in Denver, CO, USA on air quality. Reportedly, in 2018 in Denver county, there were over 600 registered cannabis cultivation facilities for recreational and medical use, mostly in commercial warehouses. The study focused on the determination of terpenes found in the headspace above cannabis plants. Reportedly, half of the total terpenes recorded across the state of Colorado were reported to be derived from Denver County alone. These increased terpene emissions from cannabis cultivation were calculated to result in an increase of up to $0.34 \mathrm{ppb}$ in the hourly ozone concentrations during the morning and $0.67 \mathrm{ppb}$ at night.

\subsection{City Air}

In one of the earliest studies focused on the levels of drugs in city air, Zaromb et al. [37] investigated the determination of airborne cocaine and heroin. Using a high-throughput liquid adsorption pre-concentration approach, air was sampled at 550-700 L/min $\mathrm{r}$. The airborne drugs were isolated in either a $0.01 \mathrm{M}$ sodium phosphate $\mathrm{pH} 7$ buffer solution or a $0.01 \mathrm{M}$ ortho-phosphoric acid solution of $0.1 \mathrm{~g} / 1$ of Triton X-100, or in. Cocaine and heroin were quantified by liquid chromatography with electrochemical amperometric detection using a mobile phase of potassium phosphate buffer ( $\mathrm{pH} 7-7.4,0.02 \mathrm{M}$ )-acetonitrile (40:60, $v / v$ ) at a flow rate of $1.0 \mathrm{~mL} / \mathrm{min}$, at a $\mathrm{C}_{18}$ stationary phase. Electrochemical detection was undertaken at a glassy carbon electrode with an applied potential of $+1.0 \mathrm{~V}$ (vs. $\mathrm{Ag} / \mathrm{AgCl}$ ).

Postigo et al. [38] investigated pressurised liquid extraction (PLE) for the extraction of atmospheric particles collected by high-volume air sampler using quartz microfiber filters. Analysis of the extracts was undertaken by liquid chromatography-tandem mass spectrometry employing selected reaction monitoring. The authors reported the presence of 17 different compounds, including cocaine and its derivatives, amphetamine and related compounds, opioids, cannabinoids and lysergic compounds. Quantitation was achieved utilising surrogated deuterated internal standards. Absolute recoveries were reported to be $50 \%$ with relative standard deviations of $<13 \%$ reported for all compounds, except for the cannabinoids. The limits of determination were reported to range from $0.35 \mathrm{pg} / \mathrm{m}^{3}$ (for 2-oxo-3-hydroxy-LSD) to $22.55 \mathrm{pg} / \mathrm{m}^{3}$ (for 11-nor-9-carboxy- $\Delta$-9-tetrahydrocannabinol). The optimised procedure was applied to the analysis of ambient air samples collected from two urban background sites in the Spanish cities of Barcelona and Madrid. The majority of sites investigated were reported to show the presence of cocaine, benzoylecgonine, $\Delta 9$ tetrahydrocannabinol, ecstasy, amphetamine, methamphetamine, and heroin. The highest daily mean levels were reported for cocaine $\left(850 \mathrm{pg} / \mathrm{m}^{3}\right)$ and for heroin $\left(143 \mathrm{pg} / \mathrm{m}^{3}\right)$.

Cecinato et al. [39] investigated the occurrence of illicit substances in the air of five South American and six European cities. The analytical procedures required for the determination of cocaine, methadone and cocaethylene were optimised. Following Soxhlet extraction with subsequent column clean-up determination by GC/MS was found to be successful for the determination of these compounds at concentrations of ca. $1 \mathrm{pg} / \mathrm{m}^{3}$ in air for sample volumes of ca. $500 \mathrm{~m}^{3}$. Apart from the Algeria capital, Algiers, and the Serbian 
city, Pančevo, cocaine was reported present in all the cities investigated with concentrations ranging from pg to $\mathrm{ng} / \mathrm{m}^{3}$ (Rome, Italy, $22 \pm 97 \mathrm{pg} / \mathrm{m}^{3}$; Santiago, Chile, $2.2 \pm 3.3 \mathrm{ng} / \mathrm{m}^{3}$ ). Reportedly the atmospheric concentrations of cocaine correlated to the prevalence of the drug in the Italian regions investigated. However, concentrations of methadone and cocaethylene in air were found to be always lower than the detection limit of the method. The method was reported to provide poor detection limits for cannabinoids, and it was concluded to be unsuitable for their determination, allowing only for the identification of cannabinol. Similar issues were highlighted for heroin $\left(35 \mathrm{pg} / \mathrm{m}^{3}\right)$; however, this compound was still quantifiable in airborne particulates from the city of Porto in Portugal. Air concentrations of cocaine collected during the winter from Bari, Rome, Milan and Taranto (right-hand $y$ axis) were reported to be proportional with its prevalence, confiscations and crime numbers (left-hand $y$ axis) (Figure 1).

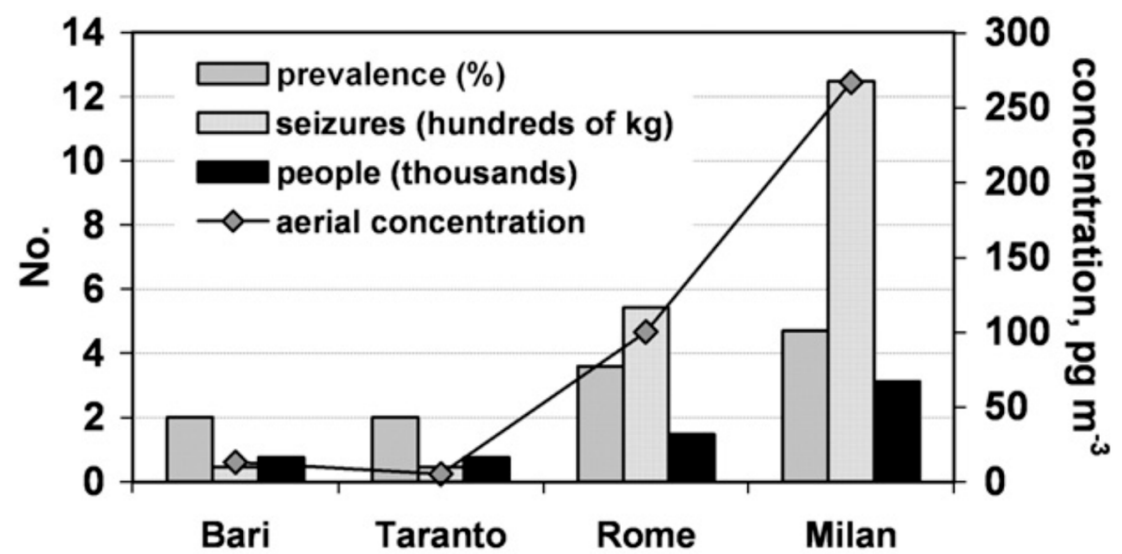

Figure 1. The rates of the prevalence of abuse, the amount of cocaine seized, number of people involved in criminal activity associated with cocaine, and the airborne concentrations of cocaine in four Italian cities. With permission from [39].

In a related investigation [40], it was shown that air cocaine concentrations correlated with the regional drug consumption in both Rome and Taranto. Studies of the total ion current chromatograms were able to show the presence of a numbers of drugs, including caffeine, nicotine, cocaine and cannabinol (Figure 2). The GC/MS analysis of carbonaceous aerosol samples showed levels of cocaine reaching $>100 \mathrm{pg} / \mathrm{m}^{3}$ at some periods. However, the drug was reported to be virtually absent in Algiers (Algeria). Italian atmospheric cocaine concentrations were found to be similar to other pollutants, such as nitrated polyaromatic hydrocarbons or polychlorobiphenyls, but greater than those of polychlorodibenzo- $p$ dioxins/polychlorodibenzofurans. Cocaine was not found to correlate with the levels of air nicotine or caffeine levels, nor with the commonly studied air pollutant, benzo[ $\alpha]$ pyrene. More notably, the levels of cocaine in the air of Rome and Taranto were reported to correlate with the amounts consumed or destroyed by the authorities in Italy. The authors highlighted airborne cocaine concentrations were in the same concentration range as many of the more commonly studied and recorded air pollutants. 


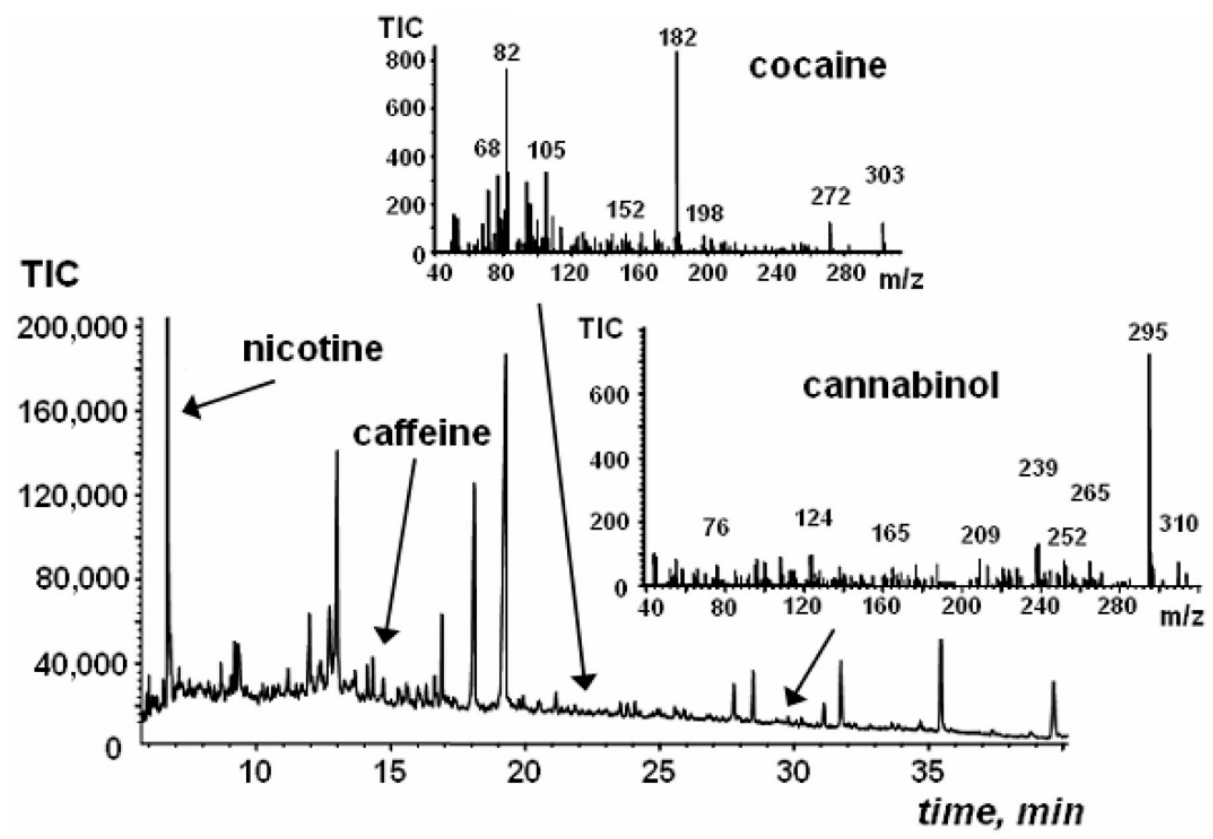

Figure 2. GC/MS profile of the highly-polar organic fraction associated with airborne particulate from a green park in downtown Rome. Insert: mass spectra of cocaine and cannabinol. With permission from [40].

In a subsequent study, Cecinato and co-workers [41] investigated the presence of illicit psychotropic substances in airborne particulates in the air of cities throughout Italy in two field campaigns undertaken in 2009. Twenty-eight localities over eight Italian regions were investigated in winter, with a further eleven sites in June (14 regions in total). The prevalent drug reported, both in rural and suburban air was cocaine. The highest levels were reported in Milan during the winter (ca. $0.39 \mathrm{ng} / \mathrm{m}^{3}$ ), with levels of up to ca. $0.16 \mathrm{ng} / \mathrm{m}^{3}$ reported in other Northern Italian cities and in Rome. The presence of $\Delta$-9-tetrahydrocannabinol, cannabidiol and cannabinol and were reported at lower concentrations than cocaine, or below detectable levels. Cannabinol was reported to account for up to $90 \%$ of their total. The overall concentrations of the illicit compounds investigated were reported to be up to six times lower in June than that reported during the winter. This decrease was postulated to result from changes in atmospheric conditions, such as lowering of the boundary layer during the winter and the increased oxidizing capacity of atmosphere during the warmer summer. A number of other common pollutants were investigated, including airborne particulates, n-alkanes, polynuclear aromatic compounds along with nicotine and caffeine. Statistical investigations using a Pearson (linear) regression coefficient did not identify any easily explainable relationship between the illicit drugs detected.

The presence of $\Delta$-9-tetrahydrocannabinol, cannabidiol and cannabinol has been investigated in airborne particulates and soot following ultrasonic extraction [42]. The extracts were then purified by solvent partitioning and then derivatized with $N-(\mathrm{t}-$ butyldimethylsilyl)- $N$-methyl-trifluoroacetamide. The resulting derivatives were then separated and quantified by GC/MS. The method was reported to be able to determine the three psychotropic substances at concentrations ranging from ca. 0.001 to ca. $5.0 \mathrm{ng} / \mathrm{cm}^{3}$ of air, with recoveries $>82 \%$. Investigations into the levels of the three drugs in air samples in the Italian cities of Rome and Bari, showed the presence of all three compounds whereas in Algiers (Algeria), only cannabinol, the most stable of the three compounds, was found in the atmosphere. The results from this study showed that the relative percentages of the three cannabinoids found in the air samples was very different from that seen in human blood, urine and sweat. However, they did reflect the ratios generally seen in the Cannabis sativa plant. 
Investigations into the levels of 17 different drugs, including cocaine and its metabolites, heroin, cannabinoids and amphetamines, were carried out in urban environments in Spain [43] at air quality monitoring sites. The reported daily mean concentrations of cocaine (204-480 pg/m $\left.{ }^{3}\right)$, were up to an order of magnitude greater than those reported in Italy and Portugal, cannabinoids ( $\Delta$-9-tetrahydrocannabinol, $\left.27-44 \mathrm{pg} / \mathrm{m}^{3}\right)$, amphetamine $\left(1.4-2.3 \mathrm{pg} / \mathrm{m}^{3}\right)$ and heroin $\left(9-143 \mathrm{pg} / \mathrm{m}^{3}\right)$ were determined in the air samples investigated. The authors reported it possible to use their results to detect temporal consumption patterns for cocaine and cannabis, being able to show week-end maxima. Investigations were also carried out on over 50 major and trace elements by inductively-coupled plasma mass and atomic emission spectrometry following the acid digestion of the air filter. Water-soluble ions, including sulphate, nitrate, chloride, ammonium and oxalate were examined by ion-exchange chromatography.

Further investigations conducted in March 2013 in Rome, Italy [44], were undertaken; however, on the levels of drugs present in indoor air in this case. The study investigated levels detectable in a coffee bar, a primary school and two residential homes. The study showed that drugs can reach concentration levels orders of magnitude greater than that seen for outdoor air, even if the drugs had been consumed at a different site. Within the two residential homes investigated, the average indoor cocaine level was reported to be $0.13 \mathrm{ng} / \mathrm{m}^{3}$ compared to an outdoor level of $0.09 \mathrm{ng} / \mathrm{m}^{3}$. However, much greater differences were reported for indoor/outdoor $\Delta$-9-tetrahydrocannabinol concentrations. Indoors levels of $6.6 \mathrm{ng} / \mathrm{m}^{3}$ were reported in comparison to outdoor levels of only $1.1 \mathrm{ng} / \mathrm{m}^{3}$. Cannabidiol reached 0.30 and $0.07 \mathrm{ng} / \mathrm{m}^{3}$ and cannabinol reached $2.3 \mathrm{ng} / \mathrm{m}^{3}$ indoors and $0.7 \mathrm{ng} / \mathrm{m}^{3}$ outdoors. Levels reported to be present in the air of the coffee bar investigated showed higher average drug levels of $0.33,4.7,14.3$ and $2.5 \mathrm{ng} / \mathrm{m}^{3}$ for cocaine, cannabidiol, $\Delta 9-$ tetrahydrocannabinol and cannabinol respectively. Cocaine was reported to be more abundant on weekdays at all sites except in the indoor air of one of the residential homes. Total cannabinoids were reported to greater on weekends at the other homes and the school site investigated. Results from regional network air sampling stations were used as a reference to compare with the indoor locations. The comparison showed that all but one of the indoor sites were more contaminated with cocaine, by a factor $\geq 1.5$, and cannabinoids were, apart from the school sample site, up to 100 times greater.

In a study undertaken by Balducci et al. [45], the possible relationship between air and wastewater levels of cocaine and cannabinoids was compared in cities from both northern and southern Europe (Figure 3). Although not being able to correlate atmospheric concentrations directly with drug prevalence using the data collected in this study, the authors were able to identify links between concentrations of cocaine and estimates of abuse calculated from wastewater analysis. The results showed that meteorology, population size and consumption habits impact the air levels of the drugs examined. It was concluded that if a better understanding of these factors could be reached, the approach could represent a simple, cost-effective method to examine the levels of cocaine abuse in an area. The United Kingdom capital of London reported the highest concentrations of cocaine with air concentration levels of 0.02 to $0.33 \mathrm{ng} / \mathrm{m}^{3}$. Amsterdam levels ranged between 0.03 to $0.14 \mathrm{ng} / \mathrm{m}^{3}$, with levels in Stockholm below the quantification limit for the method of $3 \mathrm{pg} / \mathrm{m}^{3}$. Cannabinol was the only cannabinoid detected across these cities. The mean cocaine levels from Amsterdam during March 2011 were reported to be comparable with those reported in the eight Italian cities investigated and comparable to that found at an urban background obtained in Milan and a densely populated site in Florence. 


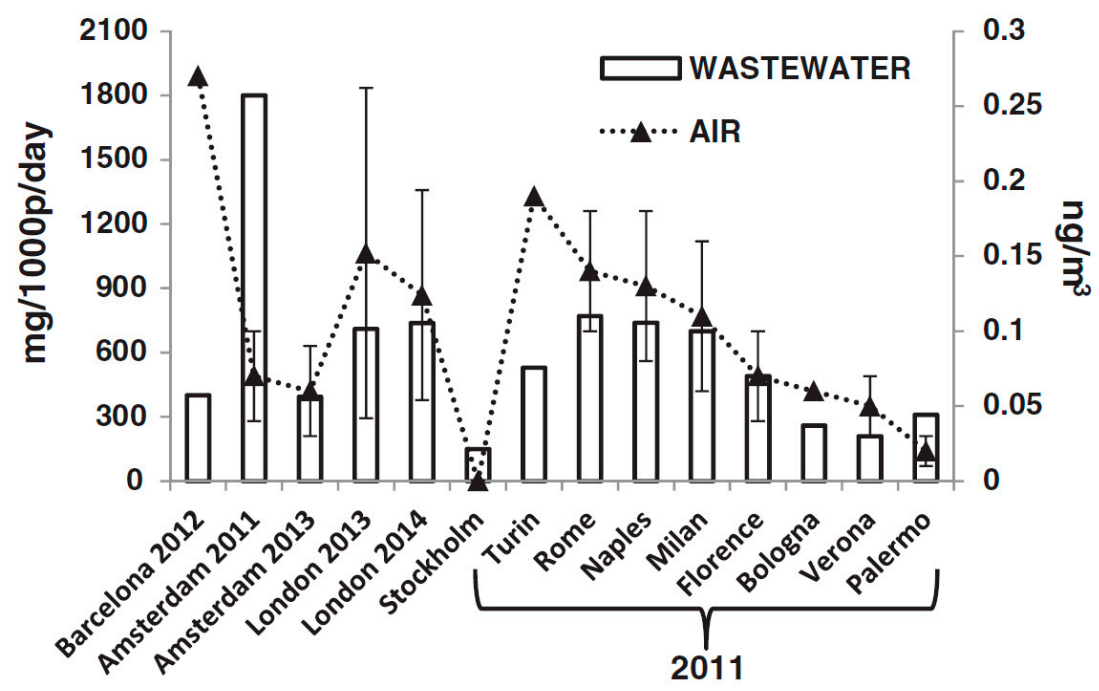

Figure 3. Average air concentrations of cocaine in various European cities and their estimated drugs abuse levels obtained from wastewater investigations from same year. With permission [45].

Temporal variations in drug use can reportedly be seen in changes in air drug concentrations [46]. The effect of events and holidays, such as the Notte Bianca (White Night) in the Italian capital of Rome, on the air concentration of drugs has been investigated. During the Notte Bianca weekend, air concentrations of cocaine were found to reach $87 \mathrm{pg} / \mathrm{m}^{3}$, over double that reported on other days. A similar increase for nicotine and caffeine were also reported with an increase from $2640 \pm 420 \mathrm{pg} / \mathrm{m}^{3}$ up to $5000 \mathrm{pg} / \mathrm{m}^{3}$, and from $260 \pm 46 \mathrm{pg} / \mathrm{m}^{3}$ up to $420 \mathrm{pg} / \mathrm{m}^{3}$, respectively. Cocaine was reported to survive sufficiently long enough periods to be collected and measured and to respond quickly to the drug abuse rate. Table 1 provides a summary of some of the more recent analytical approaches discussed in Section 2, Section 3, Section 4, Section 5. 
Table 1. Determination of air concentrations of psychoactive drugs.

\begin{tabular}{|c|c|c|c|c|c|c|c|}
\hline Drug(s) Determined & Sample & Extraction & $\begin{array}{c}\text { Column, Mobile } \\
\text { Phase/Temperature Program }\end{array}$ & Detector & Limit of Detection & Comments & Ref. \\
\hline Methamphetamine & $\begin{array}{c}\text { Indoor air from former } \\
\text { clandestine } \\
\text { methamphetamine } \\
\text { laboratory sites. }\end{array}$ & $\begin{array}{l}\text { Solid phase } \\
\text { microextraction. }\end{array}$ & $\begin{array}{c}\mathrm{GC} ; 40^{\circ} \mathrm{C}(2.5 \mathrm{~min}), 40^{\circ} \mathrm{C} / \mathrm{min} \\
\text { to } 300^{\circ} \mathrm{C}(3 \mathrm{~min}) .30 \mathrm{~m} \mathrm{HP}-5 \mathrm{MS} \\
0.25 \mathrm{~mm} \text { internal diameter, } \\
0.25 \mu \mathrm{m} \\
\text { 5\%-phenyl-methylpolysiloxane. } \\
\text { He carrier gas. }\end{array}$ & $\begin{array}{l}\text { MS; full scan mode } \\
\text { from } m / z \text { 38-300. }\end{array}$ & & $\begin{array}{l}\text { Air concentrations } \\
\text { compared to surface } \\
\text { wipe results. }\end{array}$ & [25] \\
\hline Methamphetamine & $\begin{array}{c}\text { Indoor air from former } \\
\text { clandestine } \\
\text { methamphetamine } \\
\text { laboratory sites. }\end{array}$ & $\begin{array}{c}\text { Capillary } \\
\text { microextraction }\end{array}$ & $\begin{array}{c}\mathrm{GC} ; 30^{\circ} \mathrm{C}, 2.5 \mathrm{~min}, 40^{\circ} \mathrm{C} / \mathrm{min}, \\
260^{\circ} \mathrm{C}, 2.5 \mathrm{~min} . \text { Restek } \\
\mathrm{RX}-5 \mathrm{MS} 30 \mathrm{~m} \times 250 \mu \mathrm{m} \times \\
0.25 \mu \mathrm{m}\end{array}$ & $\begin{array}{l}\text { MS; full scan mode } \\
\text { from } m / z \text { 38-300. }\end{array}$ & & $\begin{array}{l}\text { Reportedly, } 30 \text { times } \\
\text { more sensitive than that } \\
\text { obtained by solid phase } \\
\text { microextraction [35]. }\end{array}$ & [26] \\
\hline $\begin{array}{l}\text { Synthetic cannabinoids: } \\
\text { ABFUBINACA, UR144, } \\
\text { MDMB 4en Pinaca, MDMB } \\
\text { CHMCA. }\end{array}$ & $\begin{array}{l}\text { Air from an English } \\
\text { prison. }\end{array}$ & $\begin{array}{l}\text { Thermal desorption of } \\
\text { personal and static } \\
\text { monitoring tubes. }\end{array}$ & $\begin{array}{c}\text { Two-dimensional gas } \\
\text { chromatography. } 40^{\circ} \mathrm{C} 2 \mathrm{~min}, \\
\text { ramped at } 5.5^{\circ} \mathrm{C} / \mathrm{min} \text { to } 25^{\circ} \mathrm{C}, \\
\text { isothermal, } 15 \mathrm{~min} \text {. Primary } \\
\text { column: } \mathrm{Rx} 1-5 \mathrm{~ms} \text {. Secondary } \\
\text { column: Bpx50. }\end{array}$ & $\begin{array}{l}\text { Time-of-flight mass } \\
\text { spectrometry. }\end{array}$ & $\begin{array}{l}\text { ABFUBINACA } 0.5 \mathrm{pg} / \mathrm{m}^{3}, \\
\text { UR144 } 1.7 \mathrm{pg} / \mathrm{m}^{3}, \text { MDMB } 4 \mathrm{en} \\
\text { Pinaca } 4.3 \mathrm{pg} / \mathrm{m}^{3}, \mathrm{MDMB} \\
\text { CHMCA } 3.8 \mathrm{pg} / \mathrm{m}^{3} .\end{array}$ & $\begin{array}{l}\text { No drugs detected in } \\
\text { samples investigated. }\end{array}$ & [28] \\
\hline $\begin{array}{c}\text { 7-aminoflunitrazepam, } \\
\text { amphetamine, } \\
\text { benzoylecgonine, clobazam, } \\
\text { clonazepam, cocaine, codeine, } \\
\text { diazepam, fentanyl, } \\
\text { flunitrazepam, ketamine, } \\
\text { lorazepam, MAM, MDMA, } \\
\text { methadone, } \\
\text { methamphetamine, } \\
\text { midazolam, morphine, } \\
\text { nordiazepam, oxazepam, } \\
\text { oxycodone, temazepam, } \\
\Delta \text {-9-tetrahydrocannabinol and } \\
\text { triazolam. }\end{array}$ & $\begin{array}{l}\text { Air present in police } \\
\text { drug safes and drug } \\
\text { storage areas. }\end{array}$ & $\begin{array}{c}\text { Solid phase } \\
\text { microextraction and } \\
\text { carbon traps } \\
(110 \times 8 \mathrm{~mm} \text {, air was } \\
\text { sampled at a rate of } \\
30 \mathrm{~mL} / \mathrm{min} \text { for } 30 \mathrm{~min} .\end{array}$ & $\begin{array}{c}\text { Carbon traps determined by } \\
\text { LC/MS/MS [5]. Solid phase } \\
\text { microextraction by GC/MS; } \\
50^{\circ} \mathrm{C}(2 \mathrm{~min}), 8^{\circ} \mathrm{C} / \mathrm{min} 280^{\circ} \mathrm{C} \\
(20 \mathrm{~min}) \text { then } 50^{\circ} \mathrm{C} / \mathrm{min} 300^{\circ} \mathrm{C} \\
(5 \mathrm{~min}) .\end{array}$ & $\begin{array}{l}\text { MS; full-scan mode } \\
\text { from } m / z 30 \text { to } 400 .\end{array}$ & 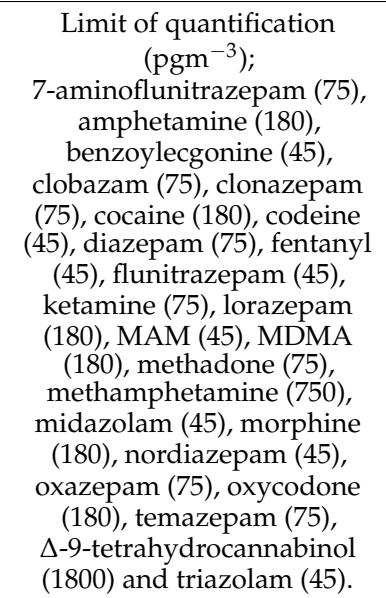 & $\begin{array}{l}\text { All of the air samples } \\
\text { were negative for all of } \\
\text { the } 22 \text { drugs } \\
\text { compounds } \\
\text { investigated. }\end{array}$ & [34] \\
\hline
\end{tabular}


Table 1. Cont.

\begin{tabular}{|c|c|c|c|c|c|c|c|}
\hline Drug(s) Determined & Sample & Extraction & $\begin{array}{c}\text { Column, Mobile } \\
\text { Phase/Temperature Program }\end{array}$ & Detector & Limit of Detection & Comments & Ref. \\
\hline $\begin{array}{c}\text { Cocaine, benzoylecgonine, } \\
\text { cocaethylene, amphetamine, } \\
\text { methamphetamine, MDMA, } \\
\text { (R,R)(-)-pseudoephedrine, } \\
(1 S, 2 \mathrm{R})(+) \text {-ephedrine } \\
\text { hydrochloride, measured } \\
\text { together as total ephedrine, } \\
\text { heroin, morphine, and heroin } \\
\text { 6-acetylmorphine, } \\
\Delta \text {-tetrahydrocannabinol } \\
\text { 11-nor-9-carboxy- } \Delta-9- \\
\text { tetrahydrocannabinol, } \\
\text { 11-hydroxy- } \Delta-9- \\
\text { tetrahydrocannabinol, lysergic } \\
\text { acid diethylamide nor-LSD } \\
\text { and nor-iso-LSD and } \\
\text { 2-oxo-3-hydroxy-LSD. }\end{array}$ & $\begin{array}{l}\text { Atmospheric particles } \\
\text { collected by } \\
\text { high-volume sampler } \\
\text { on quartz microfiber } \\
\text { filters. Flow rate of } \\
30 \mathrm{~m}^{3} / \mathrm{h} \text { for } 24 \mathrm{~h} \text { with } \\
\mathrm{PM}_{2.5} \text { cut-off inlets. }\end{array}$ & $\begin{array}{l}\text { Pressurized Liquid } \\
\text { Extraction. }\end{array}$ & $\begin{array}{l}\text { LC/MS/MS. RP- } 18 \text { end capped } \\
\text { column }(125 \mathrm{~mm} \times 2.0 \mathrm{~mm}, \\
5 \mu \mathrm{m}) \text {, guard column }(4 \times 4 \mathrm{~mm} \text {, } \\
5 \mu \mathrm{m}) \text { of the same packing } \\
\text { material. Gradient } \\
\text { acetonitrile/water flow rate of } \\
300 \mu \mathrm{L} / \mathrm{min} \text {. Injection volume, } \\
5 \mu \mathrm{L} \text {. }\end{array}$ & $\begin{array}{l}\text { MS/MS, positive } \\
\text { ionisation positive ion } \\
\text { mode, electrospray. }\end{array}$ & $\begin{array}{c}\text { Range from } 0.35 \mathrm{pg} / \mathrm{m}^{3} \text { (for } \\
\text { 2-oxo3-hydroxy-LSD) to } \\
22.55 \mathrm{pg} / \mathrm{m}^{3} \text { (for } \\
\text { 11-nor-9 carboxy } \\
\Delta \text {-9-tetrahydrocannabinol). }\end{array}$ & $\begin{array}{c}\text { Air samples from } \\
\text { Barcelona and Madrid } \\
\text { (Spain). }\end{array}$ & [38] \\
\hline $\begin{array}{l}\text { Cocaine, methadone and } \\
\text { cocaethylene }\end{array}$ & Air filters. & $\begin{array}{l}\text { Soxhlet extraction with } \\
\text { subsequent column } \\
\text { clean-up. }\end{array}$ & $\begin{array}{c}\text { GC/MS. Restek RTX-MS type } \\
\text { capillary gas chromatography } \\
\text { column }(30 \mathrm{~m}, 250 \mu \mathrm{m}, \\
0.30 \mu \mathrm{m} \text { film. }\end{array}$ & $\begin{array}{l}\text { MS, selected ion } \\
\text { monitoring. }\end{array}$ & $\begin{array}{l}\text { ca. } 1 \mathrm{pg} / \mathrm{m}^{3} \text { in air for sample } \\
\text { volumes of ca. } 500 \mathrm{~m}^{3} .\end{array}$ & $\begin{array}{l}\text { Five South American } \\
\text { cities and six } \\
\text { European cities }\end{array}$ & [39] \\
\hline
\end{tabular}


Table 1. Cont.

\begin{tabular}{|c|c|c|c|c|c|c|c|}
\hline Drug(s) Determined & Sample & Extraction & $\begin{array}{c}\text { Column, Mobile } \\
\text { Phase/Temperature Program }\end{array}$ & Detector & Limit of Detection & Comments & Ref. \\
\hline $\begin{array}{c}\text { Cocaine, } \\
\Delta \text { 9-tetrahydrocannabinol, } \\
\text { cannabidiol and cannabinol, } \\
\text { nicotine and caffeine. }\end{array}$ & & $\begin{array}{l}\text { Soxhlet extraction with } \\
\text { dichloromethane/acetone } \\
\text { (4:1) with subsequent } \\
\text { column clean-up. }\end{array}$ & GC/MS. & $\begin{array}{l}\text { Select ion monitoring } \\
\text { mode. }\end{array}$ & $\begin{array}{l}\text { Limit of quantification, } \\
\qquad 8 \mathrm{pg} / \mathrm{m}^{3}\end{array}$ & $\begin{array}{l}\text { Twenty-eight localities } \\
\text { over eight Italian } \\
\text { regions investigated in } \\
\text { winter, with a further } \\
\text { eleven sites in June } \\
\text { (14 regions in total). }\end{array}$ & [41] \\
\hline $\begin{array}{l}\Delta \text { 9-tetrahydrocannabinol, } \\
\text { cannabidiol and cannabinol. }\end{array}$ & Airborne particulates. & $\begin{array}{c}\text { Sonication. extracts } \\
\text { purification by solvent } \\
\text { partitioning and } \\
\text { derivatized with } N-(\mathrm{t}- \\
\text { butyldimethylsilyl)- } N \text { - } \\
\text { methyl- } \\
\text { trifluoroacetamide. }\end{array}$ & $\begin{array}{l}\text { GC/MS/MS. RTX-MS type } \\
\text { Restek }(30 \mathrm{~m}, 250 \mu \mathrm{m}, 0.30 \mu \mathrm{m} \\
\text { film), } 60 \text { to } 170^{\circ} \mathrm{C} \text { at } 15^{\circ} \mathrm{C} / \mathrm{min} \text {, } \\
\text { to } 290^{\circ} \mathrm{C} \text { at } 4{ }^{\circ} \mathrm{C} / \mathrm{min}, \\
\text { isothermal for } 15 \mathrm{~min} .\end{array}$ & & $\begin{array}{c}\text { Limits of detection: } \\
\Delta 9 \text {-tetrahydrocannabinol } \\
600 \mathrm{pg} / \mathrm{mL} ; \text { cannabidiol } \\
700 \mathrm{pg} / \mathrm{mL} \text {; cannabinol } \\
200 \mathrm{pg} / \mathrm{mL} .\end{array}$ & $\begin{array}{l}\text { Airborne particulates } \\
\text { collected from Rome } \\
\text { and Bari, (Italy) and } \\
\text { Algiers (Algeria). }\end{array}$ & [42] \\
\hline $\begin{array}{c}\text { Cocaine, benzoylecgonine, } \\
\text { cocaethylene, amphetamine, } \\
\text { methamphetamine, MDMA, } \\
(\mathrm{R}, \mathrm{R})(-) \text { pseudoephedrine, } \\
(1 \mathrm{~S}, 2 \mathrm{R})(+) \text {-ephedrine } \\
\text { hydrochloride, measured } \\
\text { together as total ephedrine, } \\
\text { heroin, morphine, and heroin } \\
\text { 6-acetylmorphine, } \\
\Delta \text {-tetrahydrocannabinol } \\
\text { 11-nor-9-carboxy- } \Delta-9- \\
\text { tetrahydrocannabinol, } \\
\text { 11-hydroxy- } \Delta-9- \\
\text { tetrahydrocannabinol, lysergic } \\
\text { acid diethylamide nor-LSD } \\
\text { and nor-isoLSD and } \\
\text { 2-oxo-3-hydroxy-LSD. }\end{array}$ & $\begin{array}{l}\text { Atmospheric particles } \\
\text { collected on quartz fibre } \\
\text { filters. }\end{array}$ & $\begin{array}{l}\text { Pressurized liquid } \\
\text { extraction. }\end{array}$ & $\begin{array}{l}\mathrm{LC} / \mathrm{MS} / \mathrm{MS} \text { and ion } \\
\text { chromatography for inorganic } \\
\text { anions. }\end{array}$ & $\begin{array}{l}\text { Selected reaction } \\
\text { monitoring. }\end{array}$ & $\begin{array}{c}\text { Limits of determination } \\
\text { between } 0.35 \mathrm{pg} / \mathrm{m}^{3} \text { for } \\
\text { 2-oxo-3-hydroxy-LSD and } \\
22.55 \mathrm{pg} / \mathrm{m}^{3} \text { for } 11 \text {-nor-9 } \\
\text { carboxy } \\
\Delta \text {-9-tetrahydrocannabinoll). }\end{array}$ & & [43] \\
\hline $\begin{array}{l}\text { Cocaine, cannabinoids and } \\
\text { particulate fractions for } \\
\text { nicotine and caffeine. }\end{array}$ & $\begin{array}{l}\text { Air from schools, homes } \\
\text { and an office in Rome, } \\
\text { Italy. }\end{array}$ & $\begin{array}{l}\text { Prototype sequential } \\
\text { samplers }\end{array}$ & GC/MS & & 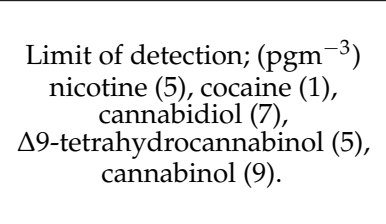 & $\begin{array}{l}\text { Seasonal variation } \\
\text { noted for drugs } \\
\text { investigated. } \\
\text { Particulates also } \\
\text { investigated for } \\
\text { polycyclic aromatic } \\
\text { hydrocarbons. }\end{array}$ & [47] \\
\hline$\Delta$ 9-tetrahydrocannabinol & Indoor air. & $\begin{array}{l}\text { Personal air-sampler } \\
\text { fitted with GC } \\
\text { liner-tube packed with } \\
\text { Tenax-TA adsorbent. }\end{array}$ & $\begin{array}{l}\text { GC; } \mathrm{HP}-5 \mathrm{MS}, 25 \mathrm{~m} \times 0.2 \mathrm{~mm} \\
\text { i.d., } 0.33 \mu \mathrm{m} \text { film thickness). He } \\
\text { carrier gas. } 40^{\circ} \mathrm{C}(1 \mathrm{~min}), \\
25^{\circ} \mathrm{C} / \mathrm{min} \text { to } 250^{\circ} \mathrm{C}(25 \mathrm{~min}) .\end{array}$ & $\begin{array}{l}\text { MS; full-scan mode } \\
\text { from } m / z 50 \text { to } 350 .\end{array}$ & $0.1 \mu \mathrm{gm}^{-3}$ & $\begin{array}{l}\text { Tenax TA packed liner } \\
\text { extracted by in-injector } \\
\text { thermal desorption. }\end{array}$ & [48] \\
\hline
\end{tabular}




\section{Airborne Drug Exposure to Health Care Workers Anaesthetic Gases Exposure}

Table 2 summaries the analytical approaches and findings obtained for investigations in the exposure of anaesthetic drugs and gases. Nitrous oxide $\left(\mathrm{N}_{2} \mathrm{O}\right)$, colloquially known as laughing gas or nitrous is commonly used as an anaesthetic, especially in surgery and dentistry. The application of $\mathrm{N}_{2} \mathrm{O}$ by health care professionals, such as midwives, has been reported to result in air concentrations that can result in possibly dangerous levels. Investigation by Henderson et al. [49] showed that air levels of $\mathrm{N}_{2} \mathrm{O}$ exceeded the legal occupational exposure standards for $\mathrm{N}_{2} \mathrm{O}$ in $76 \%$ of midwives investigated. Midwives wore a passive sampling tube during the first four hours of their shift, placed within their breathing zone. This consisted of a steel tube packed with molecular sieve 5A with a diffusive cap on top. The levels of adsorbed $\mathrm{N}_{2} \mathrm{O}$ were then determined by thermal desorption gas chromatography with electron capture detection.

Byhahn et al. [50] also investigated $\mathrm{N}_{2} \mathrm{O}$ air exposure along with the anaesthetic gas sevoflurane. Their investigation used a similar approach, with a passive sampler placed in the breathing zone of paediatric surgeons, however, in this case, using a direct-reading photoacoustic infrared spectrometer. The study was undertaken in operating theatres equipped with waste anaesthetic gas scavengers and air conditioning. Results showed the surgeon and the anaesthesiologist to be exposed to low concentrations of both drugs. However, the concentrations found were below the threshold limits of 25 ppm for $\mathrm{N}_{2} \mathrm{O}$ and 2 ppm for sevoflurane recommended by the National Institute of Occupational Safety and Health. Notably, exposure to sevoflurane and $\mathrm{N}_{2} \mathrm{O}$ was reported to be higher during the surgery of young children compared to teenagers.

Further studies [51,52] have investigated possible occupational exposure to methoxyflurane by hospital emergency room nurses overseeing patients inhaling methoxyflurane. Methoxyflurane can be self-administered by patients using devices, such as the hand-held Penthrox 'green whistle' inhaler. Patients inhale vaporised liquid through the mouthpiece and then exhale this back into the device. Exhaled methoxyflurane is then captured in a chamber containing activated carbon. Despite the activated carbon chamber to capture exhaled methoxyflurane, it is possible that exposure to methoxyflurane vapour in the air could occur. A formal exposure limit of a maximum of 8-h TWA limit of $15 \mathrm{ppm}$ had been set. However, the human odour detection threshold for methoxyflurane is very low, at $0.15 \mathrm{ppm}$ and consequently, reports highlight the drug's odour is frequently detectable [51,52]. As a result, there is a need to monitor staff exposure to methoxyflurane vapour and this has been undertaken in two investigations using passive personal monitoring devices based on activated charcoal in a hospital emergency department [51] and in bone marrow biopsy [52]. In one study, a 3M Organic Vapor Monitor 3500 badge sampler [53] was applied. These were extracted with the aid of ultrasonication for $10 \mathrm{~min}$ with carbon disulphide. Quantification of methoxyflurane was then undertaken by GC/MS using toluene as an internal standard. The lower limit of quantification was reported as $1 \mu \mathrm{g} /$ sample. For 30 out of the 31 badge samplers investigated methoxyflurane concentrations were reported to be below the limit of quantification.

McAuliffe et al. [54] and Gold et al. [55] developed an LC/MS/MS based method to determine the airborne levels of fentanyl and propofol in the air present in a hospital operation theatre. Aerosolized fentanyl was reported to be detectable in air sampled from the cardiothoracic operating room in a number of areas. These included the patients expiratory circuits, headspace above the sharps' disposal bins, but reportedly, not in the air of adjoining hallways. Aerosolized propofol was reported to be detected in the exhaled air of a patient undergoing prostate surgery. Fentanyl was extracted from air samples collected in $500 \mathrm{~mL}$ glass bottles containing $50 \mathrm{~mL}$ of methanol. Samples were taken from the hospital cardiovascular surgery suite and its adjacent hallway, from the air outside and from a separate building. The bottles containing the sampled air and methanol were put in a shaker for $20 \mathrm{~min}$. The methanol extract was then evapourated and the 
resulting residue reconstituted in $1 \mathrm{~mL}$ of water. The resulting extract was then subjected to solid-phase extraction (SPE) and the resulting eluate evaporated and reconstituted for liquid chromatography/mass spectrometry, using multiple reaction monitoring $(\mathrm{m} / \mathrm{z}$ $337.4 \rightarrow 188.4$ transition). Chromatographic separation was undertaken using a mobile phase of $70 \%$ acetonitrile-water with $0.1 \%$ formic acid at a flow rate of $400 \mu \mathrm{L} / \mathrm{min}$. The authors also examined exhaled breath from patients undergoing prostate surgery using propofol as an anaesthetic collected in $2 \mathrm{~L}$ Teflon environmental collection bags. The specimens were acquired at time points between 5 and $30 \mathrm{~min}$ following the intravenous administration of propofol, with a baseline measurement taken beforehand. The exhaled breath specimens were analysed using solid-phase microextraction (SPME) and GC/MS. Propofol was reported not to be detectable in the baseline specimen, but was recorded in each exhaled breath samples examined taken during propofol infusion.

Air concentrations of the anaesthetics, isoflurane and sevoflurane in Brazilian hospital operating rooms were investigated by Braz et al. [56]. Operating rooms without active waste air scavenging systems were found to be associated with adverse health effects. Infrared spectroscopic investigations of air concentrations of isoflurane and sevoflurane were undertaken from the respiratory area of the anaesthesiologist and the assistant nurse and at the anaesthesia station at 12 and 30 min following the start of surgery. In unscavenged operating rooms, air concentrations of isoflurane and sevoflurane were reported to be higher than the US recommended limit of $2 \mathrm{ppm}$. In the scavenged operating rooms investigated, the average concentrations of isoflurane were reported to be below the US exposure limit, apart for the measurements obtained near the anaesthesia station. However, sevoflurane, concentrations exceeded the limit value at measurement locations and at both times. The exposure to both anaesthetics exceeded the international limit in un-scavenged operating rooms. 
Table 2. Determination of anaesthetic gas and drugs in air

\begin{tabular}{|c|c|c|c|c|c|c|c|}
\hline Drug(s) Determined & Sample & Extraction & $\begin{array}{c}\text { Column, Mobile } \\
\text { Phase/Temperature } \\
\text { Program }\end{array}$ & Detector & Limit of Detection & Comments & Ref. \\
\hline $\mathrm{N}_{2} \mathrm{O}$ & $\begin{array}{l}\text { Passive sampling tube } \\
\text { placed within the } \\
\text { breathing zone, packed } \\
\text { with molecular sieve 5A. }\end{array}$ & Thermal desorption & $\begin{array}{l}\text { Gas chromatography. HP } \\
\text { Plot } \mathrm{Q}, 30 \mathrm{~m} \times 0.53 \mathrm{~mm} \text { ID } \\
\text { column. Isothermal } 30^{\circ} \mathrm{C} \text {. }\end{array}$ & $\begin{array}{l}\text { Electron capture } \\
\text { detection }\end{array}$ & & $\begin{array}{c}\text { Air samples in } 76 \% \text { of } \\
\text { midwife shifts exceeded } \\
\text { occupational exposure } \\
\text { standards. }\end{array}$ & [49] \\
\hline $\begin{array}{c}\mathrm{N}_{2} \mathrm{O} \text { and } \\
\text { sevoflurane. }\end{array}$ & $\begin{array}{c}\text { Passive sampler placed } \\
\text { in the breathing zone of } \\
\text { paediatric surgeons. }\end{array}$ & & & & & $\begin{array}{l}\text { Concentrations below the } \\
\text { threshold limits. }\end{array}$ & [50] \\
\hline Methoxyflurane. & $\begin{array}{l}\text { Occupational exposure } \\
\text { by nurses in emergency } \\
\text { room and in bone } \\
\text { marrow biopsy } \\
\text { procedures, using a } 3 \mathrm{M} \\
\text { Organic Vapor Monitor } \\
3500 \text { badge sampler. }\end{array}$ & $\begin{array}{l}\text { Badge samplers } \\
\text { extracted in carbon } \\
\text { disulphide with } \\
\text { ultrasound. }\end{array}$ & Gas chromatography. & $\begin{array}{l}\text { Mass spectrometry, } \\
\text { using toluene as an } \\
\text { internal standard. }\end{array}$ & $\begin{array}{l}\text { The lower limit of } \\
\text { quantification was } \\
1.0 \mu \mathrm{g} / \text { sample. }\end{array}$ & $\begin{array}{c}\text { Concentrations below the } \\
\text { limit of quantification in } 30 \\
\text { of } 31 \text { badge samplers } \\
\text { investigated. }\end{array}$ & {$[51,52]$} \\
\hline $\begin{array}{l}\text { Propofol and } \\
\text { fentanyl. }\end{array}$ & $\begin{array}{l}\text { Air samples collected in } \\
\text { hospital operating } \\
\text { theatres. }\end{array}$ & $\begin{array}{c}\text { SPE, following } \\
\text { solvent extraction } \\
\text { with methanol of air } \\
\text { sample for fentanyl. } \\
\text { SPME extraction for } \\
\text { Propofol. }\end{array}$ & $\begin{array}{c}\text { LC/MS/MS. Multiple } \\
\text { reaction monitoring mode } \\
m / z 337.4 \rightarrow 188.4 \text { for } \\
\text { fentanyl. Xterra } C_{8} \text { column } \\
(3.0 \times \cdot 250 \mathrm{~mm}, 5 \mu \mathrm{m}), \\
\text { guard column. Mobile } \\
\text { phase: acetonitrile-water } \\
0.1 \% \text { formic acid (70:30), } \\
400 \mu \mathrm{L} / \mathrm{min} .\end{array}$ & & Qualitative. & $\begin{array}{l}\text { Air samples from } \\
\text { operating theatre were } \\
\text { positive for fentanyl. } \\
\text { Samples taken outside } \\
\text { theatre were negative. } \\
\text { Sample of patient's breath } \\
\text { positive for propofol. } \\
\text { Others reported negative. }\end{array}$ & {$[54,55]$} \\
\hline $\begin{array}{l}\text { Isoflurane and } \\
\text { sevoflurane. }\end{array}$ & $\begin{array}{l}\text { Brazilian hospital } \\
\text { operating rooms. }\end{array}$ & & & $\begin{array}{c}\text { Infrared } \\
\text { spectroscopy. }\end{array}$ & & $\begin{array}{l}\text { Exposure to both } \\
\text { anaesthetics exceeded the } \\
\text { international limit in the } \\
\text { air of un-scavenged } \\
\text { operating rooms. }\end{array}$ & [56] \\
\hline
\end{tabular}




\section{Conclusions}

There has been a strong focus of studies on environmental air pollution and some have highlighted correlations between air concentrations found and those reported in other media, such as wastewater and natural distributions in the source plants. Investigations of the effects of firsthand and secondhand smoking of drugs, such as cocaine, cannabis and opium, generally show secondhand smoke effects to be limited, apart from in the case of opium. This also highlights the problems of accumulated drug residues, from their smoking, resulting in what is commonly referred to as thirdhand smoke and from their manufacture. The storage of drugs, such as cannabis, can result in strong odours being formed and the exposure to such, concluded by individuals to result in adverse effects. However, the effects have been attributed to growth of moulds and exposure to their spores. The occupational exposure of anaesthetic gas and drugs, such as $\mathrm{N}_{2} \mathrm{O}$, would seem to be an issue for healthcare workers, especially in buildings without air scavenging units. For the general population, the levels of airborne drugs do not seem to represent an issue. However, the sampling of drugs in air is not a common part of the majority of investigations and may be underrepresented.

Author Contributions: Conceptualisation, investigation, writing-review and editing, supervision, funding acquisition, K.C.H. Writing-review and editing, P.Z.-A. All authors have read and agreed to the published version of the manuscript.

Funding: This research received no external funding.

Institutional Review Board Statement: Not applicable.

Informed Consent Statement: Not applicable.

Acknowledgments: The authors would like to thank the support of the University of the West of England, Centre for Research in Biosciences for funding this research with a summer bursary P.Z.-A. We would like to thank the researchers whose work has been described in this review.

Conflicts of Interest: The authors declare no conflict of interest.

\section{References}

1. Davoli, E.; Zuccato, E.; Castiglioni, S. Illicit drugs in drinking water. Curr. Opin. Environ. Sci. Health 2019, 7, 92-97. [CrossRef]

2. Emke, E.; Evans, S.; Kasprzyk-Hordern, B.; de Voogt, P. Enantiomer profiling of high loads of amphetamine and MDMA in communal sewage: A Dutch perspective. Sci. Total Environ. 2014, 487, 666-672. [CrossRef] [PubMed]

3. Smith, F.P.; McGrath, K.R. Cocaine surface contamination and the medico-legal implications of its transfer. Egypt. J. Forensic Sci. 2011, 1, 1-4. [CrossRef]

4. Viegas, S.; Pádua, M.; Veiga, A.C.; Carolino, E.; Gomes, M. Antineoplastic drugs contamination of workplace surfaces in two Portuguese hospitals. Environ. Monit. Assess. 2014, 186, 7807-7818. [CrossRef]

5. $\quad$ Doran, G.S.; Deans, R.M.; De Filippis, C.; Kostakis, C.; Howitt, J.A. Quantification of licit and illicit drugs on typical police station work surfaces using LC-MS/MS. Anal. Methods 2017, 9, 198-210. [CrossRef]

6. Bowdler, P.; Gale, E.; Bryant, F.; Codd, S.; Hudd, S.; Longden, R.; White, P.; Honeychurch, K.C. Illicit drug contamination of the Bristol Pound local currency. Forensic Sci. Int. 2020, 316, 110469. [CrossRef]

7. Serrano, K.A.; Martyny, J.W.; Kofford, S.; Contreras, J.R.; van Dyke, M.V. Decontamination of Clothing and Building Materials Associated with the Clandestine Production of Methamphetamine. J. Occup. Environ. Hyg. 2012, 9, 185-197. [CrossRef]

8. Gent, L.; Paul, R. Air monitoring for illegal drugs including new psychoactive substances: A review of trends, techniques and thermal degradation products. Drug Test Anal. 2021, 13, 1078-1094. [CrossRef]

9. Ordoveza, F.; West, P.W. Microdetermination of caffeine using the ring oven technique. Anal. Chim. Acta 1964, $30,227-233$. [CrossRef]

10. Dong, M.; Hoffmann, D.; Locke, D.C.; Ferrand, E. The occurrence of caffeine in the air of New York city. Atmos. Environ. 1967, 11, 651-653. [CrossRef]

11. Williams, D.C.; Whitaker, J.R.; Jennings, W.G. Measurement of Nicotine in Building Air as an Indicator of Tobacco Smoke Levels. Environ. Health Perspect. 1985, 60, 405-410. [CrossRef] [PubMed]

12. Hammond, S.K.; Leaderert, B.P. A Diffusion Monitor to Measure Exposure to Passive Smoking. Environ. Sci. Technol. 1987, 21, 494-497. [CrossRef] [PubMed]

13. Pandey, S.K.; Kim, K.H. A review of environmental tobacco smoke and its determination in air. TrAC 2010, 29, 804-819. [CrossRef] 
14. Apelberg, B.J.; Hepp, L.M.; Avila-Tang, E.; Gundel, L.; Hammond, S.K.; Hovell, M.F.; Hyland, A.; Klepeis, N.E.; Madsen, C.C.; Navas-Acien, A.; et al. Environmental monitoring of secondhand smoke exposure. Tob. Control 2013, 22, 147-155. [CrossRef] [PubMed]

15. Green, D.E. Highly Sensitive, Adaptable, Procedures for Mass Spectrometric Real-time Monitoring of Drugs and Other Compounds. Intrascience Chem. Rep. 1970, 4, 211-221. [CrossRef]

16. Baltazar-Martins, G.; del Mar Plata, M.; Muñoz-Guerra, J.; Argaya, J.; Del Coso, J. Chronicle of an unintentional MDMA intoxication of a field hockey team to prevent its qualification for the Beijing 2008 Olympics: A case report. Drug Test Anal. 2020, 12, 647-650. [CrossRef] [PubMed]

17. U.S. Department of health and Human Services. Research Findings on Smoking of Abused Substances; Chiang, C.N., Hawks, R.L., Eds.; NIDA Research Monograph 99; 1990. Available online: https://archives.drugabuse.gov/sites/default/files/monograph99.pdf (accessed on 27 October 2020).

18. Holitzki, H.; Dowsett, L.E.; Spackman, E.; Noseworthy, T.; Clement, F. Health effects of exposure to second- and third-hand marijuana smoke: A systematic review. CMAJ Open. 2017, 5, E814-E822. [CrossRef] [PubMed]

19. Cone, E.J.; Johnson, R.E.; Darwin, W.D.; Yousefnejad, D.; Mell, L.D.; Paul, B.D.; Mitchell, J. Passive Inhalation of Marijuana Smoke: Urinalysis and Room Air Levels of Delta-9-Tetrahydrocannabinol. J. Anal. Toxicol. 1987, 11, 89-96. [CrossRef]

20. Herrmann, E.S.; Cone, E.J.; Mitchell, J.M.; Bigelow, G.E.; LoDico, C.; Flegel, R.; Vandrey, R. Non-Smoker Exposure to Secondhand Cannabis Smoke II: Effect of Room Ventilation on the Physiological, Subjective, and Behavioral/Cognitive Effects. Drug Alcohol Depend. 2015, 151, 194-202. [CrossRef]

21. Sempio, C.; Lindley, E.; Klawitter, J.; Christians, U.; Bowler, R.P.; Adgate, J.L.; Allshouse, W.; Awdziejczyk, L.; Fischer, S.; Bainbridge, J.; et al. Surface Detection of THC Attributable to Vaporizer Use in the Indoor Environment. Sci. Rep. 2019, 9, 18587. [CrossRef]

22. Cone, E.J.; Yousefnejad, D.; Hillsgrove, M.J.; Holicky, B.; Darwin, W.D. Passive Inhalation of Cocaine. J. Anal. Toxicol. 1995, 19, 399-411. [CrossRef] [PubMed]

23. Bitter, J.L. The persistence of illicit drug smoke residues and their recovery from common household surfaces. Drug Test. Anal. 2016, 9, 603-612. [CrossRef]

24. Goldberger, B.A.; Martin, D.M.; Gold, M.S. Opium Smoke: The Study of Second-and Third-Hand Exposure in Women and Children of Afghanistan, U.S. Department of State's Bureau for International Narcotics and Law Enforcement Affairs (INL). 2010. Available online: https:/ /2009-2017.state.gov/documents/organization/141833.pdf (accessed on 1 December 2021).

25. McKenzie, E.J.; Miskelly, G.M.; Butler, P.A. Detection of methamphetamine in indoor air using dynamic solid phase microextraction: A supplementary method to surface wipe sampling. Anal. Methods 2013, 5, 5418-5424. [CrossRef]

26. Nair, M.V.; Miskelly, G.M. Capillary microextraction: A new method for sampling methamphetamine vapour. Forensic Sci. Int. 2016, 268, 131-138. [CrossRef]

27. Bocos-Bintintan, V.; Ghira, B.G.; Anton, M.; Martiniuc, V.A.; Ratiu, A.I. Sensing Precursors of Illegal Drugs—Rapid Detection of Acetic Anhydride Vapors at Trace Levels Using Photoionization Detection and Ion Mobility Spectrometry. Molecules 2020, 25, 1852. [CrossRef]

28. Paul, R.; Smith, S.; Gent, L.; Sutherill, R. Air monitoring for synthetic cannabinoids in a UK prison: Application of personal air sampling and fixed sequential sampling with thermal desorption two-dimensional gas chromatography coupled to time-of-flight mass spectrometry. Drug Test Anal. 2021, 13, 1-8. [CrossRef]

29. Ross, S.A.; El Sohly, M.A. The volatile oil composition of fresh and air-dried buds of Cannabis sativa. J. Nat. Prod. 1996, 59, 49-51. [CrossRef]

30. Martyny, J.W.; Serrano, K.A.; Schaeffer, J.W.; van Dyke, M.V. Potential exposures associated with indoor marijuana growing operations. J. Occup. Environ. Hyg. 2013, 10, 622-639. [CrossRef]

31. Doran, G.S.; Deans, R.M.; DeFilipis, C.; Kostakis, C.; Howitt, J.A. Work place drug testing of police officers during large volume cannabis seizures. Forensic Sci. Int. 2017, 275, 224-233. [CrossRef]

32. Smith, M.V. Psychedelic Chemistry; Loompanics Unlimited Port Townsend: Washington, DC, USA, 1981; ISBN 0-915179-10-5.

33. Fent, K.W.; Durgam, S.; West, C.; Gibbins, J.; Smith, J.; Cincinnati, O.H.; U.S. Department of Health and Human Services; Centers for Disease Control and Prevention; National Institute for Occupational Safety and Health. NIOSH. Health Hazard Evaluation Report: Evaluation of Police Officers' Exposures to Chemicals While Working Inside a Drug Vault-Kentucky. NIOSH HETA No. 2010-0017-3133. 2011. Available online: https://www.cdc.gov/niosh/hhe/reports/pdfs/2010-0017-3133.pdf (accessed on 25 August 2021).

34. Doran, G.S.; Deans, R.; De Filippis, C.; Kostakis, C.; Howitt, J.A. Air Quality Inside Police Drug Safes and Drug Storage Areas. J. Anal. Toxicol. 2018, 42, 360-364. [CrossRef] [PubMed]

35. Hood, L.V.S.; Dames, M.E.; Barry, G.T. Headspace Volatiles of Marijuana. Nature 1973, 242, 402-403. [CrossRef] [PubMed]

36. Wang, T.C.; Wiedinmyer, C.; Ashworth, K.; Harley, P.C.; Ortega, J.; Rasool, Q.Z.; Vizuete, W. Potential regional air quality impacts of cannabis cultivation facilities in Denver, Colorado. Atmos. Chem. Phys. 2019, 19, 13973-13987. [CrossRef]

37. Zaromb, S.; Alcaraz, J.; Lawson, D.; Woo, C.S. Detection of airborne cocaine and heroin by high-throughput liquid-absorption preconcentration and liquid chromatography-electrochemical detection. J. Chromatogr. 1993, 643, 107-115. [CrossRef] 
38. Postigo, C.; de Lopez Alda, M.J.; Mar, V.; Querol, X.; Alastuey, A.; Artiñano, B.; Barceló, D. Determination of Drugs of Abuse in Airborne Particles by Pressurized Liquid Extraction and Liquid Chromatography-Electrospray-Tandem Mass Spectrometry. Anal. Chem. 2009, 81, 4382-4388. [CrossRef] [PubMed]

39. Cecinato, A.; Balducci, C.; Nervegna, G. Occurrence of cocaine in the air of the World's cities An emerging problem? A new tool to investigate the social incidence of drugs? Sci. Total Envrion. 2009, 40, 1683-1690. [CrossRef]

40. Cecinato, A.; Balducci, C. Detection of cocaine in the airborne particles of the Italian cities Rome and Taranto. J. Sep. Sci. 2007, 30, 1930-1935. [CrossRef]

41. Cecinato, A.; Balducci, C.; Budetta, V.; Pasini, A. Illicit psychotropic substance contents in the air of Italy. Atmos. Environ. 2010, 44, 2358-2363. [CrossRef]

42. Balducci, C.; Nervegna, G.; Cecinato, A. Evaluation of principal cannabinoids in airborne particulates. Anal. Chim. Acta 2009, 641, 89-94. [CrossRef]

43. Viana, M.; Querol, X.; Alastuey, A.; Postigo, C.; de López Alda, M.J.; Barceló, D.; Artíñano, B. Drugs of abuse in airborne particulates in urban environments. Environ. Int. 2010, 36, 527-534. [CrossRef]

44. Cecinato, A.; Balducci, C.; Romagnoli, P.; Perilli, M. Behaviours of psychotropic substances in indoor and outdoor environments of Rome, Italy. Environ. Sci. Pollut. Res. 2014, 21, 9193-9200. [CrossRef]

45. Balducci, C.; Green, D.C.; Romagnoli, P.; Perilli, M.; Johansson, C.; Panteliadis, P.; Cecinato, A. Cocaine and cannabinoids in the atmosphere of Northern Europe cities, comparison with Southern Europe and wastewater analysis. Environ. Int. 2016, 97, 187-194. [CrossRef] [PubMed]

46. Cecinato, A.; Balducci, C.; Nervegna, G.; Tagliacozzo, G.; Allegrini, I. Ambient air quality and drug aftermaths of the Notte Bianca (White Night) holidays in Rome. J. Environ. Monit. 2009, 11, 200-204. [CrossRef]

47. Cecinato, A.; Romagnoli, P.; Perilli, M.; Patriarca, C.; Balducci, C. Psychotropic substances in indoor environments. Environ. Int. 2014, 71, 88-93. [CrossRef]

48. Choua, L.S.; Ling, C.Y.; Yang, H.M.; Pai, Y.C. Determination of $\Delta$ 9-tetrahydrocannabinol in indoor air as an indicator of marijuana cigarette smoking using adsorbent sampling and in-injector thermal desorption gas chromatography-mass spectrometry. Anal. Chim. Acta 2007, 598, 103-109. [CrossRef]

49. Henderson, K.A.; Matthews, I.P.; Adisesh, A.; Hutchings, A.D. Occupational exposure of midwives to nitrous oxide on delivery suites. Occup. Environ, Med. 2003, 60, 958-961. [CrossRef]

50. Byhahn, C.; Heller, K.; Lischke, V.; Westphal, K. Surgeon's Occupational Exposure to Nitrous Oxide and Sevoflurane during Pediatric Surgery. World J. Surg. 2001, 25, 1109-1112. [CrossRef]

51. Frangos, J.; Belbachir, A.; Dautheville, S.; Jung, C.; Herklotz, K.; Amon, F.; Dickerson, S.; Chomier, B. Non-interventional study evaluating exposure to inhaled, low-dose methoxyflurane experienced by hospital emergency department personnel in France. BMJ Open 2020, 10, e034647. [CrossRef]

52. Ruff, R.; Kerr, S.; Kerr, D.; Zalcberg, D.; Stevens, J. Occupational exposure to methoxyflurane administered for procedural sedation: An observational study of 40 exposures. Br. J. Anaesth. 2018, 120, 1435-1437. [CrossRef]

53. 3M Air Monitoring Guide: User Instructions 3500/3510, 3520/3530, 3550/3551. Available online: https://multimedia.3m.com/ mws/media/1558692O/3m-air-monitoring-guide-3500-series-user-instructions.pdf (accessed on 25 January 2021).

54. McAuliffe, P.F.; Gold, M.S.; Bajpai, L.; Merves, M.L.; Frost-Pineda, K.; Pomm, R.M.; Goldberger, B.A.; Melker, R.J.; Cendan, J.C. Second-hand exposure to aerosolized intravenous anesthetics propofol and fentanyl may cause sensitization and subsequent opiate addiction among anesthesiologists and surgeons. Med. Hypotheses 2006, 66, 874-882. [CrossRef]

55. Gold, M.S.; Melker, R.J.; Dennis, D.M.; Morey, T.E.; Bajpai, L.K.; Pomm, R.; Frost-Pineda, K. Fentanyl Abuse and Dependence. J. Addict. Dis. 2006, 25, 15-21. [CrossRef]

56. Braz, L.G.; Braz, J.R.C.; Cavalcante, G.A.S.; Souza, K.M.L.; Mariana, M.C.L.; Braz, G. Comparação de resíduos de gases anestésicos em salas de operação com ou sem sistema de exaustão em hospital universitário brasileiro. Rev. Bras. Anestesiol. 2017, 67, 516-520. [CrossRef] [PubMed] 